\title{
DEVELOPMENT OF INVENTORS' ACTIVITIES IN LATVIA: INVENTORS' SOCIETIES, EXHIBITIONS, PATENTS AND THE RATIONALIZERS' MOVEMENT
}

\section{IVANS GRIN,EVIČS*}

Latvian Association for the History of Science

\begin{abstract}
Summary. The article introduces inventors' activities and inventors' societies in Latvia in the 18th century, when it was part of tsarist Russia, until 2019. There is only one study on inventors' activities, which includes the interwar period. There are many engineers among inventors, and this study reflects the participation of students, graduates and lecturers of Riga Polytechnicum (RP), Riga Polytechnic Institute (RPI) and Riga Technical University (RTU) in inventors' activities. The research provides an insight into the history of protection of inventions, inventors' activities, international exhibitions of inventions and innovations, activities of inventors' societies.
\end{abstract}

Keywords: exhibitions of inventions, inventors' societies, Riga Polytechnic Institute, Riga Technical University.

\section{Introduction}

The history of scientific-technological inventions and the protection of rights of inventors go deep into the past. In the territory of presentday Latvia, the protection of inventions began in the 18th century when Latvia was part of tsarist Russia and inventions were protected by a privilege (patent name in Russia until 1917). When the Republic of Latvia was established, the authorship of inventions and the author's right to an invention were protected by a legal document - a patent. After World War II, when Latvia was part of the Union of Soviet Socialist Republics (USSR), inventors' activities were wide spread, and so was the rationalization movement.

\footnotetext{
* Corresponding author.

E-mail: biedriba_inflanty@inbox.lv
} 
The invention may relate to a device, method, substance or biological material. An invention is a technical solution to a problem as a result of creativity, which differs from already existing solutions and has a positive effect and practical application. Of the vast range of inventions, only a few have been registered, much less put into production.

Inventions registered in the Republic of Latvia have been protected by patents for 100 years. In order to fight for their rights and jointly solve various problems and promote inventors' activities, inventors' societies were established, which have been operating in Latvia for almost a hundred years.

The aim of the article is to provide a comprehensive insight into inventors' activities in Latvia since the 19th century, highlighting the most significant events and decisions, as well as to reveal the contribution of RP, RPI and RTU students, graduates and lecturers to inventors' activities.

\section{The Beginnings of Patenting in Tsarist Russia}

Until the creation of an independent state of Latvia, the activities of inventors in the territory of present-day Latvia were protected by the legislation of tsarist Russia. In Russia, until the 1917 revolution, inventions were protected by privilege.

The privilege was the prerogative to produce and use. Privileges were given to people who invented something. In Russia, they began to be issued in the middle of the 18th century. The first privilege was given on 2 March 1748 to merchants Anton Tavlev (Антон Тавлев; ?-?), Terentij Voloskov (Терентий Волосков; 1729-1806) and Ivan Dedov (Иван Дедов; ?-?) for the construction of factories for producing paints according to their recommended method. By 1812, 76 privileges had been granted in production, trade and inventions in crafts and arts. On 17 June 1812, a manifesto «On Privileges for Various Inventions and Discoveries in Crafts and Arts» was signed. On 10 December of the same year, the Ministry of the Interior issued Ukaz (in Russia: the order of the monarch, also a decision of a high authority, which had the force of law) granting privileges to Robert Fulton (1765-1815), a resident of New York City, United States of America, for the installation and use of a steampowered aircraft invented in Russia. It was the first time that privileges were granted under the Manifesto of 1812. On 22 November 1833, the «Regulation on Privileges» was published, which set high standards for inventions and process of examining them $[1,2]$.

In 1870, a new Ukaz was published in Russia «0n Changes in the Records of the Procedure for Issuing Privileges to New Discoveries and 
Inventions». If the application complied with the rules of the Ukaz, the state authorities had to grant the privilege. The names of both Russian and foreign inventors can be found in the documents granting privileges in Tsarist Russia. From 1813 to 1917, 36079 privileges were granted: $29730(82.4 \%)$ to foreign inventors and 6349 (17.6\%) to Russian inventors $[1,2]$. The last law concerning inventions in Tsarist Russia was adopted in 1896 - the «Regulations on the Privileges of Invention and Development» - with amendments in 1900 and 1912. In Russia, there was a Technical Affairs Committee (1896-1918), which reviewed applications and granted privileges. Joseph Roncszewsky (Рончевский Иосиф Игнатьевич; 1864-1921), a graduate of RP (1889), a Professor of the Tomsk Institute of Technology, had served on this committee as an expert on matters of privilege and invention [3].

Figure 1. Electrograph constructed by student of the Department of Engineering of RPI Jēkabs Pilsātnieks

(early 20th century).



RP/RPI students and lecturers were also involved in inventor's activities. For example, Jēkabs Pilsātnieks (1880-1946), who studied in the Department of Engineering of Riga Polytechnic Institute (18991913), constructed an electrograph in the first years of his studies and described its operation and advantages in the Riga Technical Society newspaper «Rigasche Industrie-Zeitung» [4].

\section{The Beginnings of Patenting and Inventors' Activities in the Republic of Latvia During the Interwar Period}

Upon gaining national independence, Latvia established its own system of protection of inventions and, in recognition of the copyright in inventions, similarly to patents in other countries, introduced legal documents certifying the authorship and copyright of inventions. 
The first activities in the field of industrial property protection in the Republic of Latvia began place in the second half of 1919 with the development of a draft law on patents and trademarks for inventions. During this time, the first patent applications and trademark applications were received, which could not be processed yet because the Patent Law had not been approved.

On 5 February 1920, by order of the Minister of Trade and Industry, the Patent Office was appointed, which began operating four days later under the auspices of the Industry Department of the Ministry of Finance. From the first days of its existence in 1920 until its closure in 1940, the Patent Office was headed by engineer Jānis Purics (1880-1954) [5; p. 19].

The Patent Office had a Patent Committee, which examined patent applications and decided on grants of patents. The Republic of Latvia used the second part of the Industrial Regulations of Tsarist Russia of 1913, which starting from Article 69 included patent laws, as the basis for creating legislation for the protection of industrial property. A number of articles of that Regulation were adapted to local circumstances. On 16 July 1919, «Amendments to the Regulations on the Procedure for Issuance of Certificates of Protection of Inventions, Models and Trade Marks and Patents» were issued in accordance with the law, which were approved on 22 December 1921. Patenting of the inventions under consideration could then begin [6].

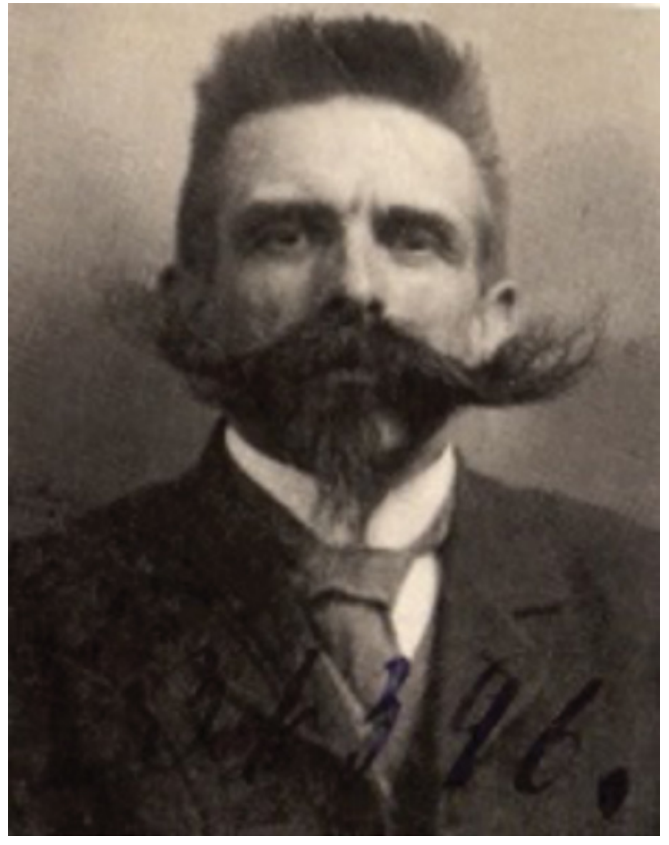

Figure 2. Inventor Andrejs Golvers (1868-1946) (1919). 
Inventions had to apply for a protection certificate before the patent was granted. The first protection certificate for the renovation of a drum-driven mill (one of the types of impact mills) was issued by the Patent Office on 15 February 1922 to Andrejs Golvers (1868-1946) from Riga [7]. He had filed a patent application with the Patent Office on 12 November 1921.

In order to quickly receive a patent for an invention, it has always been important to properly file the application, especially the description of the invention, so that the Patent Office's industry expert can recognize the innovation and recommend that the Patent Office grants patents to applicants. The Patent Office of the Republic of Latvia granted the first three patents in 1922. The first two patents were granted to foreigners - Techno-Chemical Laboratories Ltd. from Great Britain and Richard Klinger GmbH from Germany, but the third to Jānis Minuss (?-?) from Riga for a portable room stove with adjustable inflow of heated air to the stove [8]. In 1923, Latvian inventors received 20 patents, among them was the aforementioned Andrejs Golvers, who received a patent No. 28 on 24 July [9], as well as former RPI student Jēkabs Pilsātnieks, who received two patents in 1923, but in total seven.

The legislation changed several times - on 17 May 1922 and on 19 March 1925. In 1925, the Law on the Protection of Inventions, Models, Factory Drawings and Trade Marks in Exhibitions was also adopted.

The most active inventors decided to establish a society - on 14 November 1923, the Registration Division of the Riga Regional Court announced that the "Latvian Society of Inventors» was registered in Riga [10]. Its Chairman was Jēkabs Pilsātnieks. The Society actively participated in international agricultural and industrial exhibitions, presenting Latvian inventions and promoting the work of foreign inventors. The Society was especially active in Riga. The members of the Society advertised their inventions at exhibitions, for example, at the 6th Riga Exhibition in the summer of 1926, where new inventions such as a monorail railway, a steam boiler water level indicator, etc. were demonstrated [11]. The Latvian Inventors' Society existed until 9 November 1936 [12].

The Latvian Inventors' Society did not have many members the inventors implemented their inventions in daily work without any registration. Only a few Latvian inventors dared to file a patent application. During the interwar period, about 350 different inventions were filed in Latvia every year. There were far less patents for inventions. The largest number of applications for filing inventions came from foreigners. Most of the applications to the Patent Office were submitted by Latvian inventors from craftsmen and farmers [13]. 


\begin{tabular}{|c|c|c|c|c|c|c|c|c|c|c|c|c|c|c|c|c|c|c|c|c|c|c|}
\hline $\begin{array}{l}\bar{\pi} \\
\stackrel{5}{0} \\
\Leftrightarrow\end{array}$ & సี & & $n$ & $\stackrel{m}{\infty} \underset{m}{m}$ & ได & $m \mid ন$ & $\stackrel{\infty}{\infty}$ & $\stackrel{0}{\sim}$ & -10 & $\begin{array}{l}\vec{U} \\
\vec{\sim} \\
-\end{array}$ & & $\sim$ & & & 4 & ᄂ? & $-\stackrel{\llcorner}{\sim}$ & 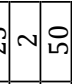 & ค. & $\vec{b} \infty$ & $\infty$ & 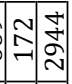 \\
\hline ㅇ. & $\Lambda$ & & & $-\rightarrow$ & &  & $\mathrm{m}$ & + & & $\stackrel{2}{-}$ & & & & & $=m$ & $\sim-1$ & & $\sim 0$ & & เ & 1 ำ & 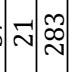 \\
\hline$\stackrel{\text { }}{\sigma}$ & 0 & & & -1 & $\mid \sim$ & $m$ & & -1 & & 능 & 0 & & & & -1 & $\rightarrow$ & & $\sim$ & & $\sim$ & $\stackrel{\infty}{m}$ & $\infty$ 웜 \\
\hline 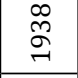 & -1 & & $\sim$ & & $m$ & 0 & $p \sim$ & -1 & & యु & \begin{tabular}{l|l}
0 & $\sim$
\end{tabular} & & & & $\nabla$ & & $\sim$ & 6 & 0 & $\sim$ & $\approx$ & 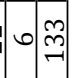 \\
\hline$\underset{\sigma}{\sigma}$ & $m$ & & & & $m$ & r & & $\sim$ & & & 의 & & & & -1 & $\sim$ & 10) & & & $\sim-$ & $-i \curvearrowright$ & เ \\
\hline 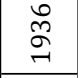 & $\wedge$ & & - & & & -0 & & & & 닝| & $\infty$ & & -7 & & $\rightarrow m$ & $m-1$ & $\rightarrow$ & & & & 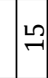 & $+\nabla$ \\
\hline $\begin{array}{l}\stackrel{L}{N} \\
\stackrel{\sigma}{\sim}\end{array}$ & เ1 & & m & & $-1 \sim$ & $m$ & & -1 & & ॰ & $\sim$ & & & & $\sim<$ & 6 & & $m$ & م & $m$ & $\vec{m}$ & $\wedge$ \\
\hline$\underset{\sigma}{\stackrel{े}{\sigma}}$ & $m$ & & $\sim$ & $\mathrm{N}|\mathrm{m}|-1$ & $-1 \sim$ & & $\sim$ & & & श & $+\mid$ & & $\rightarrow$ & & $\sim \sim \rho$ & $m$ & $m$ & $\sim$ & $\mathrm{v}$ & -1 & $\dot{m}$ & เก \\
\hline 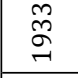 & $N$ & & ᄂ? & & $\sim$ & $\underset{7}{7}$ & & $m$ & & $\stackrel{\infty}{\wedge}$ & เก & & & & $m b$ & $0-1$ & $\sim$ & -1 & -1 & 10. & 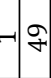 & न \\
\hline$\stackrel{\text { }}{\sigma}$ & $\nabla$ & & $\sim$ & $\nabla$ & & $m$ & & & & $\stackrel{\infty}{+}$ & & & & & -1 & $\sim \rightarrow$ & $\sim$ & $\sim$ & & 누 & $\stackrel{2}{m}$ & $\infty$ \\
\hline ले & 인 & & N & \begin{tabular}{l|l|l|l|l|l} 
& 1
\end{tabular} & ก & & $\mathrm{N} \sim$ & -1 & & 늠 & $\nabla-$ & & & & $\mathrm{Na}$ & $m \mid-1$ & $\rightarrow$ & $m$ & & เก & ข & $m$ \\
\hline 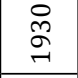 & $\Lambda$ & & & $\mathrm{s} / \mathrm{N}$ & ง 10 & & $-1 N$ & & & & $\approx$ & & & & $\sim \mid$ & เ) $\rightarrow$ & $m$ & $\sim$ & & $m$ & $-m$ & ( \\
\hline $\begin{array}{l}\text { ๙े } \\
\text { ने }\end{array}$ & $\Rightarrow$ & & - & $-\sim \sim \sim$ & $v \mid m$ & - & & $\sim$ & & ง & $\stackrel{2}{\rightarrow}$ & & & & & - & & $m$ & & $\sim$ & $-1 \stackrel{\sim}{N}$ & $\stackrel{0}{\rightarrow}$ \\
\hline$\underset{\sim}{\stackrel{\sim}{\sim}}$ & $\nexists$ & & & $\sim \mathrm{m}$ & 0 & & & & & $\Rightarrow$ & $\stackrel{\sim}{N}$ & & & & $\mathrm{~m} / \mathrm{m}$ & & $m$ & $N$ & +4 & $\sigma$ & -1 至 & $\infty \infty$ \\
\hline సે & $\Rightarrow$ & & N & $\mathrm{n} \rightarrow \mathrm{A}$ & 4.4 & $m m$ & $\mathrm{~N}$ & & & 4 이 & 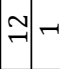 & & & & $m \mid$ & - & & $\sim$ & & $m$ & 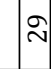 & 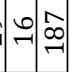 \\
\hline 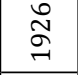 & $m$ & & & $\Delta|\backsim|-1$ & $\begin{array}{ll}-1 & 0\end{array}$ & $\infty$ & $m$ & & & 4 & $\wedge$ & & & & $m-$ & - & $\sim$ & $m$ & & & $N \stackrel{\infty}{\sim}$ & $\rightarrow \infty$ \\
\hline$\stackrel{\stackrel{L}{N}}{\stackrel{\sigma}{\sigma}}$ & 听 & & & & | & 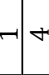 & $\sim \sim \sim$ & & & & 누 & & & & $N$ & & & & & $\sim$ & 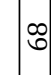 & $\sim \stackrel{\text { 兄 }}{\sim}$ \\
\hline$\underset{\sim}{\stackrel{H}{\sigma}}$ & $\infty$ & & + & $A \sim \mathrm{A}$ & $v \diamond$ & & 20 & & & 뉴 & $\cong$ & $\sim$ & & -1 & $N$ & $\sim$ & -1 & 10 & & 0 & ஓి & $\forall \rightarrow$ \\
\hline$\underset{\sim}{\stackrel{\sim}{\sigma}}$ & เ & & & $\Rightarrow m$ & ○ & & & & & 이 & -1 & & & & & เก) & & $m$ & ค & -1 & m. & 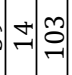 \\
\hline$\underset{\sim}{\widetilde{N}}$ & & & & & & & & & & -1 & & & & & & & & & & & $\neg$ & 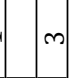 \\
\hline 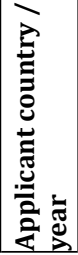 & 死 & & 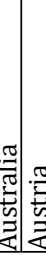 & : &  & 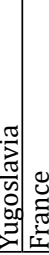 & : & $=\frac{\pi}{9}$ & 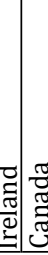 & 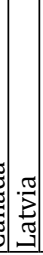 & 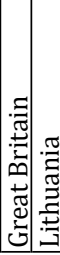 & $\mid$ & 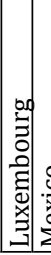 &  & 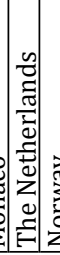 &  & 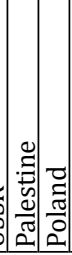 & : & تี &  & 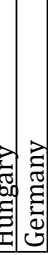 & 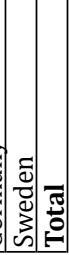 \\
\hline
\end{tabular}




\section{Activities of Rationalizers During the Interwar Period and World War II}

Along with the inventors, there were also rationalizers who tried to make the production process or the production of products cheaper, more effective, and simpler. The aim of rationalization was to achieve maximum success with minimal resources. In order to promote the activities of rationalizers and evaluate their achievements, in the autumn of 1928, the first exhibition of work rationalization exhibition was organized in Riga, initiated and organized by Fricis Galenieks (1896-1969), a specialist in agriculture and beekeeping, and a brother of RPI graduate (1917) Pauls Galenieks (1891-1962) [14]. At the end of 1928, an exhibition of agricultural facilities and work rationalization was organized by the Latvian Central Society of Agriculture. Exhibitions of this kind were held in the following years as well, and specialists from various fields gave speeches about rationalization drawing on the experience of foreign rationalizers. Engineers too addressed the issues of rationalization. For example, Herberts Pestmalis (1891-1962), a graduate of RPI (1915) and a lecturer of the University of Latvia, wrote brochure «Darba racionalizācija: noteikumi darba ražības pacelšanai darbnīcās, birojos un darba grupās» («Rationalization of Work: Rules for Increasing Productivity in Workshops, Offices and Workgroups») (1930) [15]. In 1938, the 23rd issue of magazine «Ekonomists» published article «Racionalizācijas vēsturiskā attīstī̌sanās» («Historical Development of Rationalization») by RPI graduate (1901), Professor of the University of Latvia Eduards Ramanis (1874-1944), which was also published in a separate edition [16]. E. Ramans' second article «Būvniecība Latvijā un tās racionalizācijas iespējas» («Construction in Latvia and Possibilities of its Rationalization») was also published in magazine «Ekonomists» and published in a separate edition (1939) [17].

On 12 December 1938, Prime Minister Kārlis Ulmanis promulgated the Law on the Institute of Economic Rationalization, envisaging that it would study all issues related to production. The institute was established under the auspices of the Ministry of Finance, «to study all issues related to production, improve work equipment and methods, as well as increase productivity in industry, crafts, trade, agriculture and construction, introduce production standards, raise product quality, reduce costs, achieve economic savings, efficiently divide labour and prevent waste of materials and energy» [18]. 
The law stated that in order to «achieve these goals, the institute would:

1) conduct research in individual enterprises, farms or special institutions, or groups of enterprises and farms regarding the desired rearrangements in the mechanization of work and equipment and in the simplification of production methods;

2) study the movement and distribution of labour force;

3) study the possibilities of improving the administrative organization of enterprises;

4) study the possibilities to standardize products according to their quality, type and size;

5) on the basis of the collected materials, develop proposals for rationalization of the mechanical and administrative work equipment of certain production sectors or enterprises;

6) promote the recruitment, selection and training of suitable workforce;

7) provide advice on issues of rationalization, standardization and work organization» [18].

Professor Aleksandrs Delvigs (1891-1975) of the University of Latvia (LU) was appointed Director of the Institute of Rationalization. Although the successful work of the Institute was interrupted by the change of state power on 17 June 1940, in one and a half years the institute issued 216 different standards. In the autumn of 1940, the institute was closed [18].

During World War II, in June 1942, the Institute of Rationalization was restored. The Institute organized two exhibitions: on 1 July 1942, «Latvijas saimniecība karā» («The Latvian Economy During War») and in 1942-1943, traveling exhibition «Saimnieko pareizi» («Manage properly») [19]. During its short operation, the Institute managed to prepare for publication book «Krāsnis un pareiza kurināšana» («Ovens and Proper Heating») (1943). Graduate of RPI (1916), Professor of wood chemistry Arvìds Kalninšs (1894-1981) of the University of Riga (the name of the University of Latvia during World War II (1942-1944)) participated in the preparation of the book [20]. The planned second book «Lauksaimnieka darbnīca» («Farmer's Workshop») was not published. The Institute of Rationalization was restored by the German occupation authorities, and at the end of the war, when power changed again, it ceased to function in the summer of 1944. Director of the Institute A. Delvigs went for refuge and did not return to Latvia. 


\section{Inventors' Activity After World War II}

After World War II, when Latvia lost its independence and became part of the USSR, the processes of rationalization and innovation continued. The press wrote about rationalization and introduction of inventions in Latvian companies and published books that have been preserved in the National Library of Latvia. In the late 1940s and early 1950s, republican congresses, seminars, meetings, and conferences of inventors and rationalizers took place. At the end of May 1949, the first republic-wide conference of inventors and rationalizers took place [21]. In 1956, the All-Union Inventors' Magazine was renewed in Moscow, but under a different title -magazine «Изобретатель» («Izobretatelj»; «Inventor»; 1929-1938) became «Изобретательство в СССР» («Izobretateljstvo v SSSR»; «Inventors' Activities in USSR»; 1956-1958) since 1958 - «Изобретатель и рационализатор» («Izobretatelj i Racionaljizator»; «Inventor and Rationalizer»). Until 1990, it was issued by the Committee of Affairs for Inventions and Discoveries under the auspices of the USSR Council of Ministers, and it was and can be read in Latvia as well.

On 17 January 1958, 20 years after the liquidation of the All-Union Inventors' Society (1932-1938), the All-Union Inventors' Society was renamed the All-Union Society of Inventors and Rationalizers (AUSIR) by a decision of the Presidium of Central Council of All-Union Trade Union of the USSR. Republican AUSIR councils were founded in the USSR. Republican Council of Latvia of All-Union Society of Inventors and Rationalizers operated from 27 February 1958 to 27 August 1991 [22]. The first congress of the All-Union Society of Inventors and Rationalizers was held in 1959. After the congress, primary organizations, innovation clubs and offices were established. For example, the first primary organization of the AUSIR in the Riga District was organized in 1960 at the Sigulda Scientific Research Farm. In 1962, the Riga District Innovators' Club was organized in the Riga District Culture House and the Riga District AUSIR Council was established. Initially, the AUSIR Council was set up only for agricultural enterprises, later it merged with industrial enterprises, but since 1967, it had been divided again [23]. Under such circumstances, the first organization of RPI AUSIR was established in 1967, uniting 130 specialists from the departments and laboratories of the Faculties of Electroenergetics, Mechanics and Machine Engineering, Chemistry and other. In 1966, they submitted about hundred inventions, half of which received positive evaluation [24, 25]. RPI AUSIR primary organization held conferences. 




Figure 3. Conference of RPI AUSIR primary organization. From the left: Assistant Professor Jānis Greivulis (1938-2010), Head of the Patent Department Māra Baltvilka, Assistant Professor Viktors Mironovs (1978).

There were also meetings of the Baltic republics, for example, an inter-republican discussion on the work of rural rationalizers and inventors of the Lithuanian SSR, the Latvian SSR, the Estonian SSR and the Belarusian SSR took place in August 1968, in Vilnius. From 1959 to 1969 , the number of members of the All-Union Society of Inventors and Rationalizers in Latvia more than quadrupled. In 1950, Latvian rationalizers submitted more than 7000 proposals with an economic effect of 4.6 million rubles, and in 1969 - more than 51000 proposals with an economic effect of 34 million rubles [26, 27].

On 27 September 1963, the First Congress of Latvian Inventors and Rationalizers was held. It was attended by 250 inventors and rationalizers from almost all industrial, construction, transport and communication companies of the Republic of Latvia. The report on the work of the Republican Council of Latvia of the All-Union Society of Inventors and Rationalizers was read by its Chairman Gunārs Rotbergs (1928-2014). At that time, 28 thousand technical creativity employees (including 15 thousand new rationalizers) were identified among Latvian inventors and rationalizers. In the four and a half years before the Congress in 1963, 767 inventions and almost 150000 rationalization proposals were put into production, which allowed Latvia to save 90 million rubles [28]. On 20 August 1970, at the exhibition of 
achievements of the Latvian National Economy in Mežaparks, Riga, the exposition "Latvijas PSR izgudrotāju sasniegumi» ("Achievements of the Inventors of the Latvian SSR») was opened.

In 1972, the number of copies of magazine «Изобретатель $u$ рационализатор» («Izobretatelj i Racionaljizator»; «Inventor and Rationalizer»), published by the All-Union Society of Inventors and Rationalizers, reached 400 000. More than a hundred different technical innovations were published in each issue. By the order of the Presidium of the Supreme Council of the USSR on 24 January 1979, an annual holiday was established - All-Union Inventors' and Rationalizers' Day, which was celebrated on the last Saturday in June. Starting from 30 June 1979, this day was also celebrated in Latvia. By this date, in 1979, 59500 authors had submitted rationalization proposals, $\sim 62$ thousand rationalization proposals and a thousand inventions had been implemented during the year; 867 author certificates for various inventions had been granted. The savings amounted to 83.8 million rubles per year [29].

The results of research of many students corresponded to the level of inventions or rationalization proposals, therefore in December 1981, RPI held the first meeting of students inventors and rationalizers. The most students who were most active inventors and rationalizers received Certificate of Honour from the AUSIR Republican Council of Latvia and RPI [30].

Rationalizers and inventors received financial and moral support. In the republics of the USSR 1959-1961, legislative acts were adopted on the establishment of honorary titles «Nopelniem bagātais izgudrotājs» («Meritorious Inventor») and «Nopelniem bagātais racionalizators» («Meritorious Rationalizer»). The badge «PSRS Izgudrotājs» («Inventor of the USSR») was created on 12 December 1974 in cooperation with the State Committee for Inventions and Discoveries of the USSR Council of Ministers and the Society of All-Union of Inventors and Rationalizers, having regard to the Order No. 575 on 20 August 1973 of the Council of Ministers of the USSR and the Central Committee of Communist Party of the Soviet Union. This badge was issued by the USSR to each author and co-author of the invention with the first author's certificate registered in the USSR State Register of Inventions after 1973, if it had been confirmed that the invention was used in the national economy. Many RPI inventors have been awarded this badge, including the current RTU Rector, Academician Leonīds Ribickis.

In the 1970s and 1980s, inventors and rationalizers received the following awards for special merits: badges with inscriptions in Russian «Лауреат конкурса ВОИР» («Laureat konkursa VOIR»; «Laureate of the AUSIR Competition»), «За активную работу в ВОИР» («Za aktivnuju 
rabotu v VOIR»; «For Active Work in AUSIR»), «Наставник ВОИР» («Nastavnik VOIR»; «AUSIR Mentor»), «Отличник изобретательства и рационализации ВОИР» («Otlichnik izobretatjelstva i racionalizaciji VOIR»; «Outstanding Inventor and Rationalizer of AUSIR»), «Отличникорганизатор технического творчества ВОИР» ("Otlichnik-organizator mehnicheskova tvorcestvo VOIR»; «Outstanding Organizer of Technical Creativity of AUSIR»), and others.

Almost every collective or Soviet farm was the primary organization of the All-Union Society of Inventors and Rationalizers. Some were more active, others not very active. In the mid-1980s, the author managed to start the activities of such an organization in the state farm «Eglaine» in Daugavpils District. Under the conditions of a shortage of spare parts, drivers of cars, tractors, combines, welders, lathes, and mechanics constantly had to come up with new technical solutions to various problems. The author, being an engineer of agricultural machinery exploitation, repair shop and garage manager, later also chief engineer of a farm, supported the rationalization activity, developed rationalization proposals himself, as well as helped others to design and write applications for monetary compensation for innovation in production. Socialist competitions for the titles of the best rationalizer and inventor took place in the districts of Latvia.

Not only students but also pupils were involved in inventors' activities. In the 1980s, in Zemgale Secondary School (Daugavpils District), the author managed to create the first organization of the All-Union Society of Inventors and Rationalizers where the 9th and 10th grade pupils were introduced to the basics of innovation through designing small agricultural machinery and various equipment that helped in the learning process on tractors and cars car construction [31]. Pupils were issued a certificate «Apliecība par racionalizācijas priekšlikumu» («Certificate of Rationalization Proposal») for innovations developed in the learning process and implemented in production [32]. The pupils of the mentioned secondary school were the best innovators in Latvia in truck driving, practical and theoretical issues, but in the All-Union Competition of Young Plowmen they were the best even in the whole Soviet Union. The author of the article, then a 16-year-old pupil of Zemgale Secondary School, in 1977, was awarded a medal «Par priekšzimigu darbu» («For Exemplary Work») by order of the Presidium of the Supreme Council of the USSR. This was the merit of the teacher innovator Romualds Jaunzems [33].

We can learn about the achievements of graduates and future engineers in anticipation of the 6th Congress of Latvian Inventors and Rationalizers from article «Nodoties jaunradei» («To pursue Creativity») in newspaper «Rigas Balss» published in February 1983 the author 
of which is Viktors Mironovs, Meritorious Inventor of the Latvian SSR, Docent and Chairman of the RPI AUSIR Council. It reads that in 1982, RPI innovators submitted 215 invention applications to the All-Union Patent Examination Institute, received 152 author's certificates and formulated 118 rationalization proposals. According to the results of the display of works of inventors and rationalizers organized by the Ministry of Higher and Secondary Special Education of the USSR, RPI held the third place. The best were the Departments of Automatic Electric Drives and Automated Electrical Systems. At that time, the best inventor of RPI was senior lecturer Leonids Ribickis, presently Professor and Rector of RTU who is still actively involved in inventors' activities and supports the Latvian Inventors' Activities movement. RPI AUSIR primary organization received great support from the Faculty of Mechanics and Machine Engineering (Dean Jānis Ozoliņ̌š) and the Patent Department (Head Māra Baltvilka). The number of RPI AUSIR primary organization members exceeded one and a half thousand, several gatherings of the institute's students inventors took place [34].

From 1960 to 1989, a popular scientific and technical journal «Zinātne un Tehnika» («Science and Technology») illustrated by the Scientific and Technical Committee of the Council of Ministers of the Latvian SSR, the Council of National Economy and the Council of Scientific and Technical Societies of the LSSR was published. It was published also in Russian. From 1990 to 1991, a socio-political and scientifically popular magazine «Zinātne un Mēs» («Science and Us») was published, with a circulation of up to 60000 copies per month.

From 1963 to 1988, seven congresses of Latvian inventors and rationalizers took place in Latvia. During this time, the number of members, reaching 180 000, increased 6.4 times. For example, from 1983 to 1988, in Latvia, 440 inventions and 300000 rationalization proposals were introduced in production, which saved 585 million rubles. 57000 authors had participated in their development [35]. During these years, university, district and republican exhibitions developed rapidly. For example, in 1966, an exhibition of inventions of RPI lecturers, postgraduate students and collaborators of scientific laboratories was organized [36], innovation shows were organized in districts by city innovators' clubs, and achievements of Latvian SSR inventors were exhibited in Mežaparks. The merits of the Latvian Agricultural Mechanization and Electrification Scientific Research Institute have to be mentioned in organizing the exhibition of inventions and rationalization proposals «Novators», which took place from 1971 to 1995 in Ulbroka, Riga District, which became the largest exposition of Latvian innovations in Latvia. 


\section{Activities of Inventors' Societies in the Renewed Republic of Latvia}

With the restoration of the national status of the Republic of Latvia in the early 1990s, the legal forms of public organizations also changed. The Council of All-Union Society of Inventors and Rationalizers of the Latvian Republic became the Latvian Society of Inventors and Rationalizers (27.08.1991-22.03.1993), and later - the Latvian Society of Inventors [22].

From 22 March 1993 to 7 February 2007, the legal address of public organization «Latvian Society of Inventors» was in Riga, 17 Škūnu Street. Its objectives were:

1) together with the state, economic and other public organizations to resolve issues that affect the legal rights and interests of members of the Latvian Society of Inventors and its organizations;

2) to promote the achievements of inventors and authors of amateur activities, the activities of the society, to organize competitions and other public events in the interests of the development of technical creativity;

3) to carry out production, economic and external economic activities in order to establish own material and technical basis for providing practical assistance to inventors in the development and implementation of their proposals;

4) to organize training for the staff and active, production specialists of the society in the field of inventions, patents, technical creativity, marketing and economic calculation;

5) to carry out business collaboration with foreign partners, exchange of delegations and specialized tourist groups.

In 2005, the re-registration of companies and public organizations began in Latvia in order to close the ones that had no actual activities. As a result, the Society of Inventors with registration No. 40008000263 was liquidated. An entry was made in the Register of Enterprises of the Republic of Latvia on 7 February 2007.

A series of inventors' meetings took place: on 19 April and 15 June 2007, at the Stockholm School of Economics in Riga: on 21 May, 17 September, 8 October and 29 October 2007 in the building of the Patent Office of the Republic of Latvia, Riga. At the meeting on 29 October, a decision was made to re-establish the Society with new statutes and board elections, as well as a press conference. 


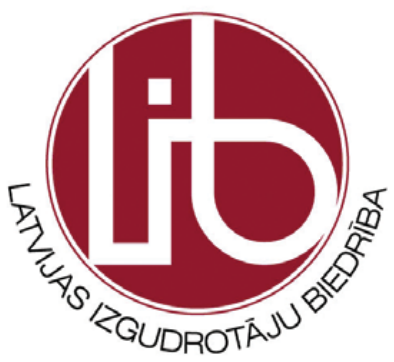

of Inventors'

Activities in

Latvia: Inventors'

Societies,

Exhibitions,

Patents and the

Rationalizers'

Figure 4. Logo of Latvian Society of Inventors (2009).

The minutes of the founding meeting record: «.. the board of the society was unanimously elected in the following composition: Aldis Eglājs (Chairman), Elmārs Baltiņš, Normunds Lazdiņš, Rims Vaitkus, Videvuds Ārijs Lapsa, and Roberts Paeglis. A decision was made to submit the Statutes of the Society to the Register of Enterprises of the Republic of Latvia. The founders of the society are all those present, as well as Sergejs Matasovs and Jänis Ratenieks, who were not present for various reasons..». After the board meeting of the Latvian Society of Inventors held on 12 November 2007, the founding documents were submitted to the Register of Societies and Foundations of the Republic of Latvia, where on 11 December 2007 it was registered with No. 40008121730, legal address of the Society: Riga, 16/20 Äzenes Street, Room 136. According to the data of the Register of Societies, in 2020 the Latvian Society of Inventors is located in Riga, 1 k-1 Prūšu Street, Room 26 [37].

The objectives of the Society are:

1) mutually share experience and provide support to the activities of members in the field of inventions, starting from the development of inventions, evaluation of the scope of patenting and filing of patent applications to marketing, realization of inventions and protection of inventors' interests;

2) to develop and submit proposals to competent state institutions for improvement of regulatory enactments for the promotion of the work of individual inventors and for financial and legal support of the implementation of inventions;

3) to provide an expert assessment to competent state institutions regarding the expected commercial value of the specific inventions and the amount of support needed;

4) to give an expert assessment to potential users of inventions and investors in production about the expected commercial value of specific inventions;

5) to establish contacts and collaborate with related organizations in Latvia and abroad in order to achieve the goals of the society and improvement of its activities;

6) to promote the activities of individual inventors in Latvia; 
7) to promote education of potential inventors in patent science;

8) to participate in exhibitions and other events dedicated to the work of inventors [38].

In addition to participating in many exhibitions, seminars and conferences, the Society itself regularly organizes exhibitions of inventions and festivals for all interested parties, as well as publishes a catalogue in two languages. For example, the first five exhibitions of inventions, which were held annually starting from 2010 , took place in the main building of RTU at $1 \mathrm{Kalk}, \mathrm{S}$ Street $[39,40,41,42,43]$.

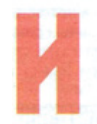

\section{«Суббота» noбbßапа на сnёте
naтßuйских uзобретатепей}
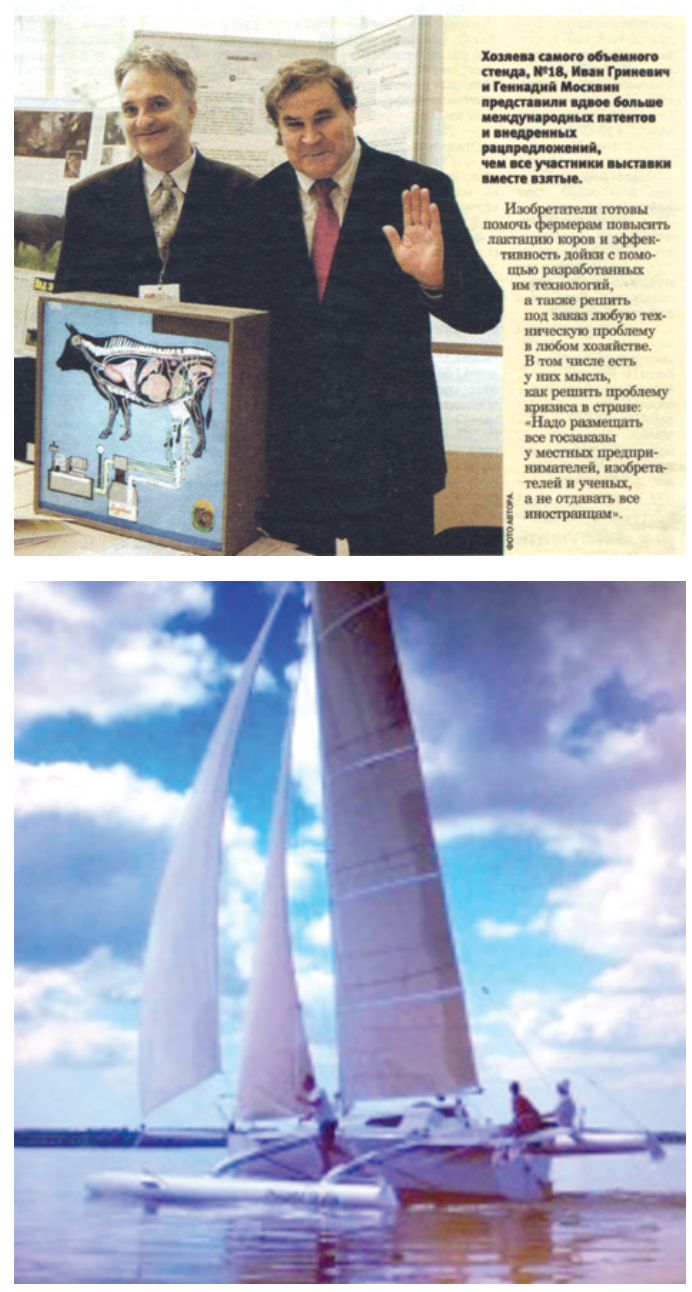

Figure 5. Participants of the Inter-university stand (No. 18) at Latvian Invention Exhibition: Ivans Griṇevičs and Genādijs Moskvins, graduate of the RPI Faculty of Instrument Engineering and Automation (1974), Professor of the Institute of Energetics of the Latvia University of Agriculture (2011).

Figure 6. Catri 25 - trimaran on underwater wings, inventor Aldis Eglājs, Chairman of the Latvian Society of Inventors (2014). 
The idea of organizing Inventors' Days and an exhibition originated in the beginning of 2008, when a delegation of the Latvian Society of Inventors (Aldis Eglājs, Mareks Justs, Normunds Lazdiņ̌̌, Roberts Paeglis) participated in the 1st International Inventors' Day in Bangkok, Thailand. For the first time, the Latvian Inventors' Day was organized along with a conference on 17 December 2008, at the Stockholm School of Economics in Riga. From 2012, to the proposal of inventor Miervalds Rozenbergs, the exhibition was re-named «MINOX» in honour of the contract concluded by inventor Valters Caps on 6 October 1936 with the State Electrotechnical Factory (VEF) for the production of camera «MINOX» [44].

Exhibition «MINOX» includes various activities to promote technical creativity and establish business contacts, such as wooden car competitions, Stirling engine design competition, solar car competition, business contact program, and educational tours to Latvian and Estonian companies. Information on intellectual property protection is regularly provided by the Patent Technical Library of the Patent Office of the Republic of Latvia. For example, the 5th International Exhibition of Inventions and Innovations «MINOX 2014» was attended by more than a hundred experienced inventors, young scientists, and innovators, who presented 68 inventions in 51 exhibitions. Nine exhibitions were prepared by young people. The inventions covered a wide range of industries. Many working prototypes, models and mock-ups were presented. Some of the inventions were patented. Alan Barrell, Professor of the University of Cambridge in the UK, also took part in the exhibition, while Leo Siemann, a representative of the Estonian Society of Inventors, gave a presentation on Estonian inventions [44].

The 6th International Exhibition of Inventions and Innovations «MINOX 2016» took place in 2016 at RTU premises in Kipsala. It was attended by about 150 inventors, scientists, innovators and young people, who presented 92 inventions or innovations in 82 exhibitions. Expositions comprised exhibits presented by 27 universities and institutes, 25 individual inventors, 13 schools and young people, 10 companies and organizations, and 7 foreign inventors - from Europe, Asia and Africa. Eight events took place during the exhibition:

1) Seminar «Izgudrojumu prezentēšanas meistarklase» («Masterclass on Presenting an Invention»);

2) Conference «Izgudrojumi tautsaimniecībai» («Inventions for the Economy») chaired by Silvija Zakke in celebration of the 80th Anniversary of Valters Caps' agreement with VEF;

3) Programme of business contacts;

4) Annual meeting of the Network of Senior Experts;

5) Meeting of Northern European Inventors' Societies; 
6) Seminar «Viḷnu enerǵijas ieguves iespējas» («Wave Energy Extraction Possibilities»);

7) Riga tour, visiting the memorial sites of Wilhelm Ostwald and Paul Walden;

8) educational excursion to Science Centre «AHHAA» in Estonia.

The presentation of the exhibition took place at the 21st International Innovation Conference of the Baltic Association of Science, Technology Parks and Innovation Centres «Baltic Dynamics 2016: Innovation and Technology Convergence - Strategy for Smart Growth» (E. Baltiñ̌s, I. Gringevičs), as well as on Latvian Radio live (I. Gringevičs, A. Kiščenko, M. Rozenbergs, L. Briede) [45].

Traditionally, all exhibitions are organized by the Latvian Society of Inventors in close collaboration with Association «CONNECT Latvija». Since 2016, the organization of the exhibition has been supported by the Latvian Academy of Sciences (LAS), including LAS Vice President and RTU Professor Andrejs Krasnikovs. In 2018, he chaired the organizing committee of the 7th International Exhibition of Inventions and Innovations «MINOX 2018» [46].

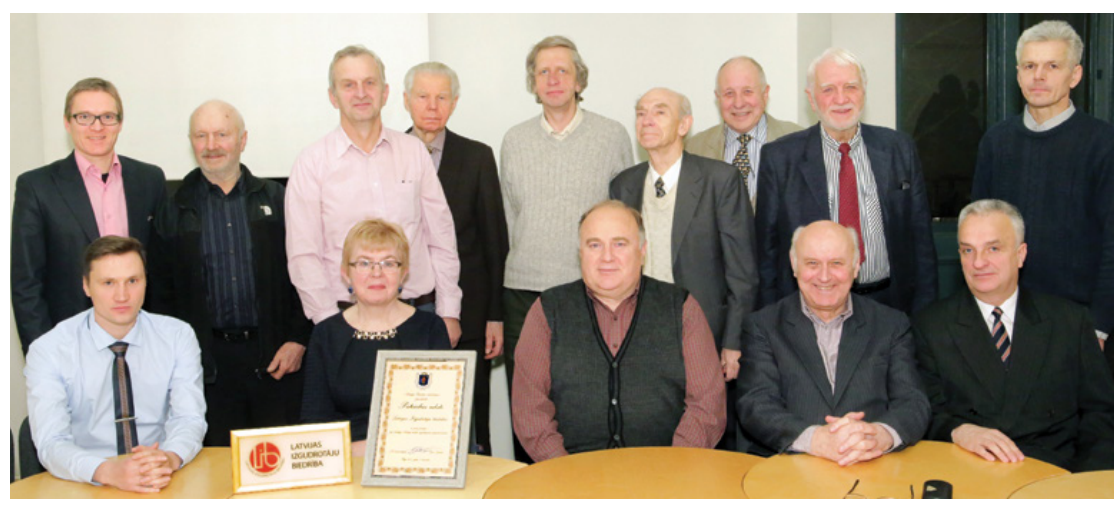

Figure 7. Members of the Latvian Society of Inventors at the 10th Anniversary of the Society with the Certificate of Gratitude from LAS President Ojārs Spārìtis. In the first row from the left: Aldis Karasevs, Silvija Zakke, Andrejs Krasnikovs, Miervaldis Rozenbergs, Ivans Grinevičs; in the second row from the left: Elmärs Baltiňš, Vilhelms Klincāns, Juris Dobrišins, Ādolfs Gertneris, Jānis Dumpis, Ernests Plarkšs, Rims Vaitkus, Videvuds Ārijs Lapsa, Zigurds Strīkis (11 December 2017).

On 11 December 2017, a solemn meeting of the Latvian Society of Inventors was held in honour of the 10th Anniversary of the newly estabished organization. The contribution of Latvian inventors to the centenary of Latvia was highly appreciated by the President of the LAS, Academician Ojārs Spārittis, who awarded the Society with a Certificate of Gratitude of the President of LAS. It was presented by LAS Vice President 
Academician Andrejs Krasnikovs at the solemn meeting of the Latvian Society of Inventors,.

Exhibition «MINOX 2018» was the first time that it took place in all cultural and historical regions of Latvia: «Minox Kurzeme», 4-5 April in Liepāja, $4 \mathrm{Kr}$. Valdemāra Street, Faculty of Natural and Engineering Sciences of Liepāja University; «Minox Latgale» on 10 May in Daugavpils, 90 Smilšu Street, RTU Daugavpils Affiliate; «Minox Vidzeme» on 2 June in Cēsis, 3 Piebalgas Street, RTU Cēsis Affiliate; «Minox Zemgale» on 8 September in Jelgava, Pasta Island; and «MINOX 2018»12-13 October in Riga, 19 Raina Boulevard, LU. About one and a half hundred inventors demonstrated their innovations in five exhibitions. Most of the exhibited inventions are included in the exhibition's bilingual catalogue, which provides descriptions of the inventions with illustrations. In the mentioned exhibition, the LAS exhibited a pumping technology with a linear peristaltic pump developed in collaboration with RTU (A. Krasnikovs, V. A. Lapsa) [46].

Since its establishment, the Chairman of the Board of the Latvian Society of Inventors has been a graduate of RPI (1962) Aldis Eglājs Chairman of the Board of LTD «Catri» and LTD «Jūras Katri». A. Eglājs has nine USSR author's certificates, 29 foreign patents and one Latvian patent. One of his best-known inventions is the trimaran with underwater wings. On 26 April 2018, World Intellectual Property Day, Sandris Laganovskis, Director of the Patent Office, and O. Spāritis, President of LAS, presented A. Eglājs with the WIPO Medal for Inventors [47].

In 2019, this medal was presented to Videvuds Ärijs Lapsa, a Board member of the Latvian Society of Inventors, Professor Emeritus of RTU, Lead Researcher of the Institute of Construction Production of Faculty of Civil Engineering, Board member of the Latvian Concrete Union. Professor V. A. Lapsa owns 34 USSR author's certificates, he is the author of 106 inventions, seven foreign and 65 Latvian patents, as well as 148 scientific publications [48].

\section{Conclusions}

Invention has a long history in Latvia, but the rights of inventors have been protected by patents for almost a hundred years. Today, patent law exists in more than 120 countries around the world, including Latvia, and is overseen by the Patent Office. At present, more than half a hundred inventors have united in the Latvian Society of Inventors, but the number of people who have turned to inventions is much higher. 
Latvian inventors, including engineers who studied at RPI and RTU, are authors of many inventions that are important in science, production and everyday life. In the second half of the 19th century and the beginning of the 20th century, they received the privilege of tsarist Russia, during the interwar period and today - patents, during the Soviet era - author's certificates. In the second half of the 20th century, the number of inventors and rationalizers among engineers increased significantly. For example, members of teaching staff Jānis Greivulis (1938-2010), Viktors Mironovs, Videvuds Ärijs Lapsa, and many others worked at RPI AUSIR. RPI graduates Ādolfs Gertneris, Antons Kiščenko, Zigurds Strīkis, and others also took part in inventors' activities. Currently, the Chairman of the Board of the Latvian Society of Inventors is RPI graduate Aldis Eglājs, the members of the Board are RPI graduate Miervaldis Rozenbergs, RTU graduate Elmārs Baltiņš, RTU Professor Emeritus Videvuds Ārijs Lapsa.

Inventors continue to realize their ideas in various projects, but the inventions can be seen in international and local exhibitions. In September and October 2020, they are «MINOX» exhibitions of innovations and inventions in Jelgava and in Kïpsala in Riga, at RTU premises.

\section{REFERENCES}

[1] Lidzhejeva, K. V. Istorija stanovlenija i razvitija dorevolyutsionnogo patentnogo prava $v$ Rossi. In: Vsetnik Kalmickovo instituta gumanitarnih issledovanij RAN, 2011, Nr. 2, s. 83-88.

[2] Istomin, S. Samije znamenitije izobretateli Rossii. Moskva: Veche, 2002, $478 \mathrm{~s}$.

[3] Grinevich, I. I. Vypusknik Rizhskovo politehnikuma Josif Roncheviskij osnovopolozhnik metalurgicheskoj laboratorii Tomskovo tehnologicheskovo instituta. In: Istorija i filosofija nauki v epohu peremen: sbornik nauchnih statej. T. 2. Moskva: Russkoje obshchestvo istorii i filosofii nauki, 2018, s. 70-72.

[4] Pilsatneeks, J. Elektrische Vorrichtung «Elektrograph» zum Fernhetrieb von Schreibmaschinen,Typendruck-Telegraphenapparaten und dergleichen. Rigasche Industrie-Zeitung, 1903, Nr. 18, S. 6.

[5] Bērziña, A. Patentu valde un izgudrotājdarbība Latvijā: 1918-1940 = The Latvian Patent Office and Inventorship in Latvia 1918-1940. Rīga: LR Patentu valde, 2018, 565 lpp.

[6] Pārgrozījumi noteikumos par izgudrojumu, model̦u un preču nozīmju aizsardzības apliecību un patentu izdošanas kārtību. Valdības Vēstnesis, 1921. gada 29. decembris, Nr. 294, 1.-2. lpp. 
[7] Rūpniecības departamenta patentu valde. Valdības Vēstnesis, 1922. gada 15. aprīlis, Nr. 85, 1. lpp.

[8] Rūpniecības departamenta patentu valde. Valdības Vēstnesis, 1923. gada 7. februāris, Nr. 30, 2. lpp.

[9] Rūpniecības departamenta patentu valde. Valdības Vēstnesis, 1923. gada 28. jūlijs, Nr. 161, 1. lpp.

[10] Tiesu sludinājumi. Valdības Vēstnesis, 1923. g. 5. decembris, Nr. 271, 11. lpp.

[11] Kas redzams 6. Rīgas izstādē? Iekšlietu Ministrijas Vēstnesis, 1926. gada 19. jūnijs, Nr. 21, 3. lpp.

[12] Tiesu sludinājumi. Valdības Vēstnesis, 1936. gada 14. novembris, Nr. 260, 7. lpp.

[13] 350 izgudrojumu gadā. Brīvā Zeme, 1940. gada 23. janvāris, Nr. 18, 5. lpp.

[14] Biroju racionalizācijas izstāde. Signāls, 1928. gada 1. oktobris, Nr. 1, 27., 28. lpp.

[15] Pestmalis, H. Darba racionalizācija: noteikumi darba ražības pacelšanai darbnīcās, birojos un darba grupās. [Rīga: b. i.], 1930, 86 lpp.

[16] Ramanis, E. Racionalizācijas vēsturiskā attīstīšanās. [Rīga: b. i.], 1938, $11 \mathrm{lpp}$.

[17] Ramanis, E. Būvniecība Latvijā un tās racionalizācijas iespējas. [Rīga: b. i.], 1939, 19 lpp.

[18] Likums par saimnieciskās racionalizācijas institūtu. Valdības Vēstnesis 1938. gada 13. decembris, Nr. 283, 1. lpp.

[19] Delvigs, A. Racionalizācijas institūta darbība. Latvju Tautsaimnieks, 1943, Nr. 3/4, 51.-56. lpp.

[20] Delvigs, A. (galv. red.). Krāsnis un pareiza kurināšana. Rīga: Saimniecības literatūras apgāds, 1943, 3. lpp.

[21] Gods un slava jaunu ceḷu meklētājiem ražošanā. Cīna, 1949. gada 27. maijs, Nr. 123, 1. lpp.

[22] Latvijas Izgudrotāju biedrība. Latvijas Valsts arhīva Latvijas Valsts arhīvs 1856. fonda izzina.

[23] VIRB-30. Darba Balss, 1988. gada 14. janvāris, Nr. 6, 1. lpp.

[24] Rīgas Politehniskā institūta izgudrotāji. Rīgas Balss, 1967. gada 1. februāris, Nr. 27, 7. lpp

[25] Izgudrotāji augstskolā. Cīnna, 1967. gada 2. februāris, Nr. 28, 4. lpp.

[26] Lauku novatoru tikšanas. Cīna, 1968. gada 2. augusts, Nr. 179, 1. lpp.

[27] Baltijas republiku izgudrotāju tikšanās. Rìgas Balss, 1968. gada 30. augusts, Nr. 204, 1. lpp.

[28] Gorbunova, I. «Tehniskā acs» dot tūkstošus. Padomju Jaunatne, 1963. gada 27. septembris, Nr. 190, 1. lpp.

[29] Apinīte, V. Novatoru svētki. Rìgas Balss, 1979. gada 30. jūnijs, Nr. 150, 2. lpp.

[30] Dzelzītis, E. Izgudrot - tas ir gandrīz vienkārši! Jaunais Inženieris, 1981. gada 24. decembris, Nr. 16, 4. lpp.

[31] Grinevich, I. I. Stremlenije k tvorchestvu vospityvajetsa s detstva. Narodnoje Obrozovanije, 1988, Nr. 3, s. 21-22. 
[32] Grinevich, I. I. Stancii i kruzhki junih tehnikov: pervij etap priobshchenija k tehnicheskomu tvorchestvu (Daugavpils). Voprosi Izobretatelstva, 1988, Nr. 3, s. 58.

[33] Kušnere, N. Skolēnam - valdības apbalvojums. Avangards, 1977. gada 12. februārī, 2. lpp.

[34] Mironovs, V. Nodoties jaunradei. Rīgas Balss, 1983. gada 23. februāris, Nr. 44, 2. lpp.

[35] Tehniskā progresa avangardā. Darba Uzvara, 1988. gada 1. marts, Nr. 34, 1. lpp.

[36] Institūta izgudrotāji - tautas saimniecībai. Padomju Jaunatne, 1966. gada 14. decembris, Nr. 242, 1. lpp.

[37] Latvijas izgudrotāju biedrības adrese [tiešsaiste]. https://company.lursoft. lv/latvijas-izgudrotaju-biedriba/40008121730 [skatīts: 11.06.2020].

[38] Latvijas Izgudrotāju biedrības arhīvs.

[39] Grinevich, I. I., Moskvin, G. A. Intelligent technologies for milk production = Intellektualnije tehnologii poluchenija moloka: katalog stendovovo referata: 3ij Mezdunarodnij forum po intelektualnoj sobstvennosti «Expopriority'2011», Mezhdunarodnaja vystavka innovacij: 7-9 dekabrja 2011 goda. Moskva: CVK «Ekspocentr»; Rembate: Mezhdunarodnij selskohozajstvennij universitet, SLU, 2011, 40 str.

[40] Moskvins, G., Griṇevičs, I. Piena ražošanas tehnoloǵiju jauninājumi: 2. Latvijas izgudrojumu izstādes stenda Nr. 18 katalogs: SLU, LLU, RTU un LU izstrādātie pañēmieni, metodes un ierīces. Rembate: SLU, 2011. 36 lpp.

[41] Starptautiskā izgudrojumu izstāde «MINOX 2012»: katalogs: 2012. gada 5.-6. oktobrī: Latvijas izgudrotāju diena 2012 = International Invention Exhibition MINOX 2012: catalogue: October 5-6, 2012: Latvian inventor's day 2012 / Latvijas izgudrotāju biedrība; biedrība «CONNECT Latvija». Rìga: RTU, 2012, 100 lpp.

[42] Latvijas Izgudrotāju biedrības un Rīgas Tehniskās universitātes pētnieku ekspozīcijas starptautiskajā izgudrojumu izstādē «MINOX 2013» / Ivana Griṇeviča redakcijā; Starptautiskā Lauksaimniecības universitāte, RTU Liepājas Zinātniskais centrs. Rembate: Liepāja, 2013, 12 lpp.

[43] 2. Starptautiskā izgudrojumu izstāde «MINOX 2013». Sastādītāji: Elmārs Baltinšš, Ivans Grinnevičs, Miervaldis Rozenbergs. Starptautiskā Lauksaimniecības universitāte, Latvijas izgudrotāju biedrība, biedrība «CONNECT Latvija», 2013, 12 lpp.

[44] Baltiṇš. E., Griṇevičs, I. (sast.). 5. Starptautiskās izgudrojumu un inovāciju izstādes MINOX 2014 katalogs = Catalogue of the 5th International Invention and Innovation Exhibition MINOX 2014: 2014. gada 10.-11. oktobrī. Latvijas izgudrotāju biedrība, biedrība «CONNECT Latvija». Rīga; Rembate: Starptautiskā Lauksaimniecības universitāte, 2015, 3. lpp.

[45] Baltiṇš. E., Dumpis, J., Griṇevičs, I. (sast.). 6. starptautiskās izgudrojumu un inovāciju izstādes «MINOX 2016» katalogs = Catalogue of the 6th International Invention and Innovation Exhibition MINOX 2016: 2016. gada 7.-8. oktobrī. Rīga: Starptautiskā Lauksaimniecības universitāte, 2016, $142 \mathrm{lpp}$. 
[46] Dumpis, J. (zin. red.). 7. starptautiskās izgudrojumu un inovāciju izstādes «MINOX 2018» katalogs = Catalogue of the 7th International Invention and Innovation Exhibition MINOX 2018. Rīga: Starptautiskā Lauksaimniecības universitāte, 2018, 161 lpp.

[47] Pasniegti Pasaules Intelektuālā īpašuma organizācijas apbalvojumi [tiešsaiste]. www.lrpv.gov.lv/lv/patentu-valde/aktualitates/zinas-noiestades/pasniegti-pasaules-intelektuala-ipasuma-organizacijas [skatīts: 04.04.2020].

[48] Videvudam Ārijam Lapsam piešķirta Pasaules Intelektuālā īpašuma «Medaḷa izgudrotājiem» [tiešsaiste]. www.rtu.lv/lv/universitate/masumedijiem/zinas/atvert/videvudam-arijam-lapsam-pieskirta-pasaulesintelektuala-ipasuma-medala-izgudrotajiem?highlight=videvuds+ārijs [skatīts: 04.04.2020].

\section{SOURCES OF ILLUSTRATIONS}

Figure 1. Rigasche Industrie-Zeitung, 1903, Nr. 18, S. 6.

Figure 2. LNA LVVA 2996. f., 7. apr., 23690. l.

Figure 3. V. Mirova personīgais arhīvs.

Figure 4. I. Griṇeviča privātarhīvs.

Figure 5. Hudenko, K. Chto izobretajut v Latvii. Subbota, 2011. gada

16.-22 novembris, Nr. 46, 20.-21. lpp.

Figure 6. 5. starptautiskās izgudrojumu un inovāciju izstādes MINOX 2014 katalogs 2014. gada 10.-11. oktobris. Latvijas izgudrotāju biedrība, biedrība «CONNECT Latvija». Rīga; Rembate: Starptautiskā Lauksaimniecības universitāte, 2015, 61. lpp

Figure 7. Jāṇa Brenča personīgais arhīvs.

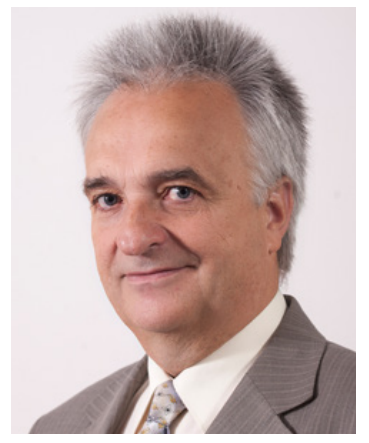

IVANS GRIN̦EVIČS, Mg. sc. ing., Mg. ing. mech., graduated from Latvia Agricultural Academy in 1984, Latvia University of Agriculture in 1992. He is a member of Latvian Society of Inventors and of Latvian Association for the History of Science. He is the author and a co-author of more than three hundred publications in Latvian, Polish, Russian, English, Lithuanian and Estonian.

Adress: 11 Plavas iela, Rembate, Rembates pag.,

Keguma nov., LV-5016, Latvia

Phone: +37129258566

E-mail: biedriba_inflanty@inbox.lv 


\section{Izgudrotājdarbības attīstība Latvijā: izgudrotāju biedrības,} izstādes, patenti un racionalizatoru kustība

Raksts iepazīstina ar izgudrotājdarbību un izgudrotāju biedrībām Latvijā no cariskās Krievijas laika 18. gadsimtā līdz 2019. gadam. Par izgudrotājdarbību līdz šim apkopojoša pētījuma nav, ir pētījums tikai par starpkaru laiku. Izgudrotāju vidū ir daudz inženieru, un šajā pētījumā atspoguḷota Rīgas Politehnikuma (RP), Rīgas Politehniskā institūta (RPI) un Rīgas Tehniskās universitātes (RTU) studentu, absolventu un mācībspēku līdzdalība izgudrotājdarbībā. Pētījumā sniegts ieskats izgudrojumu aizsardzības vēsturē, izgudrotājdarbībā, starptautiskajās izgudrojumu un inovāciju izstādēs, izgudrotāju biedrību darbā.

Atslēgas vārdi: izgudrojumu izstādes, izgudrotāju biedrības, Rīgas Politehniskais institūts, Rīgas Tehniskā universitāte. 